\title{
Vegetational response to short-duration and continuous grazing in southcentral New Mexico
}

\author{
MICHAEL R. WHITE, REX D. PIEPER, GARY B. DONART, AND LINDA WHITE TRIFARO
}

\begin{abstract}
Vegetational response of a nine-paddock, short-duration grazing cell was compared to that of a continuous pasture for a 5-year period in southcentral New Mexico. Differences in vegetational response to short-duration and continuous grazing on blue grama rangeland were small. Basal plant cover was slightly higher for the short-duration pastures, but end-of-season standing crop of all species was similar for both systems. Blue grama aboveground productivity and basal cover were higher for the short-duration pastures than for the continuously-grazed pasture. Possible shortterm results from short-duration grazing include slightly higher stocking rates and a positive response of blue grama.
\end{abstract}

Key Words: primary production, defoliation, Bouteloua gracilis

Interest in short-duration grazing in the United States has peaked since these ideas were introduced by Goodloe (1969) and elaborated by Savory $(1978,1979,1983,1988)$ and Savory and Parsons (1980). This grazing strategy has been promoted as a means of utilizing livestock grazing and associated activities to increase primary production and improve conditions for many other uses of rangelands.

While many ranchers have adopted some form of short-duration grazing (e.g., Armijo 1982, Kelton 1982, Tiedeman and Ecret 1986, and Sparks 1987), long-term research results are scarce. Researchers have been intrigued by the possibilities offered by short-duration grazing and research has been conducted in several states and 2 symposia have been convened (Briske and Kothmann 1982, Tiedeman 1986).

Short-term results comparing some form of short-duration grazing with continuous grazing have shown mixed results from the standpoint of livestock and vegetational responses. Early studies in

\footnotetext{
Authors are former graduate student, professors, and former graduate student, Department of Animal and Range Sciences, New Mexico State Univ., Las Cruces. Journal Article 1519, New Mexico Agricultural Experiment Station.

Manuscript accepted 25 October 1990
}

Texas indicated primary productivity increased under shortduration grazing compared to ungrazed controls in some years (Heitschmidt et al. 1982). Other studies have shown increases in composition of grass species considered valuable from a grazing standpoint (Corbett 1984, Dahl et al. 1982). Several studies showed only slight, or inconsistent, differences in vegetational response to short-duration grazing (Pitts and Bryant 1983, Reece et al. 1984, Reece 1986, Hart et al. 1988, Heitschmidt et al. 1987, and Anderson 1988). Other studies have shown heavy stocking could not be maintained with short-duration grazing (Ralphs et al. 1980, Thurow et al. 1988).

Short-duration grazing trials have been underway in southern Africa for some time. Skovlin (1987) reviewed results from these studies and concluded there is no improvement in range condition attributable to short-duration grazing. In northern Mexico, shortduration grazing did not reduce standing crop gradients induced by grazing away from water (Soltero et al. 1989). The hypothesis that short-duration grazing would allow substantial stocking increases has not been supported by these studies.

However, blue grama-dominated rangeland is fairly resistant to heavy grazing (Branson 1953, Smoliak 1974) and might respond to short-duration grazing strategies. Consequently, a short-duration cell was added to the other systems being studied at Ft. Stanton in southcentral New Mexico (Pieper et al. 1978). The objective was to compare vegetational response to short-duration grazing at a heavy stocking rate with continuous grazing at a moderate stocking rate.

\section{Description of Area}

Field research for this study was conducted at the 10,552-ha Fort Stanton Cooperative Experimental Ranch. The ranch is in southcentral New Mexico, about $20 \mathrm{~km}$ northeast of Ruidoso. The climate is characterized by cool winters and warm summers. The 
mean annual temperature is $11.1^{\circ} \mathrm{C}$. Mean minimum is $-6.7^{\circ} \mathrm{C}$ in January and mean maximum $28.9^{\circ} \mathrm{C}$ in July (Pieper et al. 1971). The 91-year average annual precipitation is $389 \mathrm{~mm}$, the majority falling between June and October. Most precipitation occurs in summer months, the result of convectional thunderstorms that are often localized, of high intensity and short duration. Topography of the ranch is characterized by steep canyons and arroyos that bisect extensive, relatively level mesas. Ranch elevations range from 1,880 to $2,460 \mathrm{~m}$.

Open grassland vegetation is found on mesas and in canyon bottoms. Blue grama (Bouteloua gracilis [H.B.K.] Lag. ex steud. dominates all sites. Other grass species include wolftail (Lycurus phleoides H.B.K.), sideoats grama (Bouteloua curtipendula [Michx.] Torr.), sand dropseed (Sporobolus cryptandrus [Torr.] Gray), and creeping muhly (Muhlenbergia repens Presl.] Hitch). Important forb species include scarlet globemallow (Sphaeralcea coccina [Pursh] Rydb.), Carruth sagewort (Artemisia carruthii Wood), zinnia (Zinnia grandiflora Nutt.), Dakota verbena (Verbena bipinnatifida Nutt), and broom snakeweed (Gutierrezia sarothrae [Pursh.] Britt. \& Rusby)! .

All vegetational data for this research were collected from the open grasslands (mesa tops) and canyon bottoms. The study area encompasses portions of a 922-ha SDG cell and portions of a single pasture of 567 ha that was moderately stocked and continuously grazed. The SDG cell was composed of 9 paddocks varying in size from 45 to 210 ha. It was established in 1980 , originally divided into 7 paddocks, and further subdivided to create 9 paddocks in 1982. Before implementation of the SDG cell, the area was grazed moderately on a seasonal basis. The continuously grazed pasture was established in 1969. Study site elevations ranged from 1,930 to $2,078 \mathrm{~m}$. The treatments were not replicated in space.

Stocking rates in the short-duration cell ranged from a low of 1.1 times that of the continuously grazed pasture in 1981 and 1982 to a high of 2 times greater in 1985 . Stocking rates were always greater in the SDG treatment than in the CG treatment, with one exception. In fall 1982, both grazing treatments were destocked of all cows due to drought conditions, and only the heifer calves were left until the following year.

Table 1. Annual precipitation ( $\mathrm{mm}$ ) by year and season' for the continuous and short duration grazing treatments.

\begin{tabular}{lrrrrrr}
\hline \hline Grazing treatment & 1980 & 1981 & 1982 & 1983 & 1984 & 1985 \\
\hline Continuous & 373 & 429 & 250 & 220 & 293 & 264 \\
$\quad$ Growing season & 99 & 46 & 148 & 253 & 156 & 132 \\
$\quad$ Dormant season & 472 & 475 & 398 & 473 & 449 & 455 \\
$\begin{array}{c}\text { Total } \\
\text { Devition from } \\
\text { the mean (\%) }\end{array}$ & +21 & +22 & +2 & +22 & +15 & +17 \\
$\begin{array}{l}\text { Short Duration } \\
\text { Growing season }\end{array}$ & $294^{2}$ & 358 & 220 & 219 & 317 & 240 \\
$\quad$ Dormant season & $20^{2}$ & 49 & 114 & 200 & 120 & 170 \\
$\begin{array}{c}\text { Total } \\
\text { Deviation from } \\
\text { the mean (\%) }\end{array}$ & $314^{2}$ & 407 & 334 & 419 & 437 & 410 \\
\hline
\end{tabular}

'Growing season: May through September.

2SDG rain gauge was not established until mid-July, figures are less than total received.

Table 1 shows annual precipitation received over the course of the study. The amount of total precipitation received was always greater in the continuously grazed pasture than in the SDG cell. Growing season precipitation was greater in the continuously grazed pasture as well, except during 1984, when it was greater in the SDG cell by $24 \mathrm{~mm}$. The amount of precipitation occurring in the continuously grazed pasture varied from 2 to $22 \%$ above the ranch mean, while, the precipitation received in the SDG cell varied from $14 \%$ lower than to $12 \%$ more than the ranch mean. However, there may still be precipitation variation within pastures which were not measured by these gauges.

The soils within the study area are classified as loams. All 3 soil series found on the study area are deep, well drained and formed in alluvium derived from mixed sources (Bailey et al. 1982). The Dioxice loam is found on the mesa top and makes up the greatest proportion of the soils within the study area. The Manzano loam is found in the swales, while the Pena-Dioxice loam is on the ridges and side-slopes of the study area.

\section{Methods}

In 1984 and 1985, herbaceous vegetation composition, basal plant cover, and litter cover data were collected by the point-step method described by Evans and Love (1957). This method consists of recording whatever occurs at the boot tip when pacing along a transect. A 2-mm diameter metal rod was used to define the sampling point at the boot tip. When a plant base was directly hit, the species was recorded; when the rod tip hit bare ground, rock or litter, the species of the nearest plant was recorded. Forty 100 -point transects were used to collect composition and cover data in both the SDG cell and the continuously grazed pasture. All transects were randomly located within the grassland portion of each grazing treatment. Transects were located within 4 paddocks of the SDG cell. From data collected, percentage plant composition, basal plant cover and litter cover, as well as percentage bare ground/rock, were calculated using methods described by Levy and Madden (1933).

Clipping was used to determine end-of-season herbaceous production. Four sampling points were randomly established in the continuously grazed pasture. In the SDG cell, comparable sampling points (in terms of composition and production potential) were randomly located, 1 in each of the 4 paddocks. Six $91 \times 61 \mathrm{~cm}$ cages were located near each sampling point to ensure the herbaceous vegetation was protected from grazing. A $61 \times 30.5-\mathrm{cm}$ quadrat was clipped to ground level within each cage. All clipped plant material was separated into the categories of blue grama, other grasses, and forbs. The plant material was bagged, oven-dried, and weighed to the nearest one-tenth gram. Clipping took place during late September and early October of each year. The cages were relocated near the sampling points after each clipping. Comparisons of end-of-season standing crop did not include the impact of grazing during the year in which the data were collected.

Aboveground net primary productivity between grazing treatment was examined during the 1985 growing season. In 2 paddocks of the short-duration cell, 12 sampling points were randomly located. In the continuously grazed pasture, 24 sampling points were randomly located, half of which corresponded to the 12 sampling points in each of the 2 sampled paddocks. The plants were first clipped at the end of a grazing cycle. All current production (by individual species) was clipped within a $61 \times 30.5-\mathrm{cm}$ quadrat at each of the 12 sampling points. The second clipping was made at the start of the next grazing cycle and the same procedure was followed. The difference in oven-dry weight represented growth for this period. First and second clippings were always within $1.5 \mathrm{~m}$ of one another at each sampling point; this helped ensure similarity of composition and production potential. To ensure that growth in the continuously grazed pasture was not removed by grazing, cages were placed over each of the 24 sampling points. This was not a concern in the SDG paddocks because cattle were not in the respective paddocks during the intervening growth period. Consumption by other herbivores was not considered. 
It was not possible to isolate treatment effects from pasture effects because the treatments were not replicated in space (Brown and Waller 1986, Hurlbert 1984, and Walker and Richardson 1986). Means and standard errors are reported. In addition, analysis of variance and least significant differences were used with locations within pastures as replications to assist in interpretation of results.

\section{Results}

\section{Cover and Composition}

Mean basal cover of all species was slightly higher on the shortduration pasture compared to the continuously grazed pasture for both 1984 and 1985 (Table 2). However, litter cover and bare

Table 2. Mean ground cover $(\%) \pm$ standard error of the mean by component and year for the continuous and short duration grazing treatments.

\begin{tabular}{lcc}
\hline \hline \multirow{2}{*}{$\begin{array}{l}\text { Component } \\
\text { Grazing treatment }\end{array}$} & \multicolumn{2}{c}{ Year } \\
\cline { 2 - 3 } Basal Plant Cover & 1984 & 1985 \\
$\quad \begin{array}{l}\text { Continuous } \\
\text { Short duration }\end{array}$ & $12.9 \pm 0.46$ & $11.6 \pm 0.37$ \\
$\quad$ Litter & $13.3 \pm 0.81$ & $12.4 \pm 0.56$ \\
$\quad$ Continuous & $31.5 \pm 1.05$ & $28.2 \pm 1.36$ \\
$\quad$ Short duration & $26.5 \pm 0.91$ & $33.2 \pm 1.38$ \\
Rock & & \\
$\quad$ Continuous & $9.3 \pm 0.85$ & $5.3 \pm 0.53$ \\
$\quad$ Short duration & $5.4 \pm 0.78$ & $3.7 \pm 0.47$ \\
Bareground & & \\
$\quad$ Continuous & & \\
$\quad$ Short duration & $46.3 \pm 1.32$ & $54.9 \pm 1.36$ \\
\hline
\end{tabular}

ground were inconsistent on the 2 sets of pastures for the 2 years. Litter cover was higher on the continuously grazed pasture in 1984 , and bare ground lower, but the reverse occurred in 1985.

Basal cover of blue grama was higher $(P=0.05$, LSD comparison) on the short-duration pastures than on the continuously grazed pasture for both years (Table 3). However, cover of blue grama declined from 1984 to 1985 under SDG but increased under continuous grazing. Basal cover of sideoats grama, creeping muhly, wolftail, and total grasses were higher on the continuously grazed pasture than on the short-duration pastures. Other grasses and forb species were present in rather small quantities in all pastures and did not exhibit consistent trends on the pastures.

Composition (based on cover) of blue grama was also consistently higher under short-duration grazing than under continuous grazing (Table 4). Blue grama composition was similar at the beginning of the study $(53.1 \%$ for short-duration paddocks and $51.5 \%$ for the continuous pasture). Composition of other grasses was slightly higher for the continuous pasture. Composition of other grasses and forbs was higher under continuous grazing than under short-duration grazing. Shrubs were minor components on all pastures.

\section{Herbage Biomass}

End-of-season total herbage biomass averaged about 1,200 $\mathrm{kg} \cdot \mathrm{ha}^{-1}$ for 6 years of the study for both sets of pastures (Table 5). For 3 years of the study, differences in herbage biomass were not consistent between the pastures. ANOVA did not show a significant difference $(P<0.05)$. Blue grama biomass was higher under continuous grazing, compared to short-duration grazing, from 1980 to 1982 but lower from 1983 to 1985 (Table 5). Average biomass of other grass species on the continuously grazed pasture exceeded that on the short-duration pastures by more than 100
Table 3. Mean basal plant cover (\%) by species and year for the continuous (CG) and short duration (SDG) graxing treatments.

\begin{tabular}{|c|c|c|c|c|}
\hline \multirow{3}{*}{$\frac{\text { Species }}{\text { Grasses }}$} & \multicolumn{4}{|c|}{ Year } \\
\hline & \multicolumn{2}{|c|}{1984} & \multicolumn{2}{|c|}{1985} \\
\hline & CG & SDG & CG & SDG \\
\hline $\begin{array}{l}\text { Aristida divaricata Humb. \& Bonpl. } \\
\text { Aristida purpurea Nutt. var. }\end{array}$ & 0.15 & 0.18 & 0.23 & 0.08 \\
\hline fendleriana (Steud.) Vasey & 0.03 & & 0.03 & 0.03 \\
\hline Bouteloua curtipendula (Michx.) Torr. & 0.63 & 0.13 & 0.28 & 0.13 \\
\hline Bouteloua gracilis (H.B.K.) Lag. & 7.08 & 10.00 & 7.28 & 8.78 \\
\hline Elymus elymoides (Raf.) Swezey. & 0.03 & 0.05 & 0.03 & 0.05 \\
\hline Elytrigia smithii (Rydb.) D.R. Dewey & & 0.03 & & 0.05 \\
\hline Hilaria jamesii (Torr.) Benth. & 0.10 & 0.10 & 0.10 & 0.03 \\
\hline Lycurus phleoides H.B.K. & 2.50 & 1.20 & 1.45 & 1.00 \\
\hline Muhlenbergia repens (Presl.) Hitch. & 0.75 & 0.50 & 0.48 & 0.25 \\
\hline Muhlenbergia torreyi (Kunth) Hitchc. & 0.33 & 0.35 & 0.13 & 0.20 \\
\hline Muhlenbergia wrightii Vasey & 0.03 & 0.05 & 1.00 & 1.10 \\
\hline Panicum obtusum H.B.K. & 0.03 & 0.03 & & \\
\hline Total Grasses 1 & 4.58 & 2.71 & 3.79 & 3.11 \\
\hline \multicolumn{5}{|l|}{ Forbs } \\
\hline $\begin{array}{l}\text { Artemisia carruthii Wood } \\
\text { Artemisia ludoviciana Nutt. subsp. }\end{array}$ & 0.20 & 0.18 & 0.08 & 0.25 \\
\hline albula (Woot.) Keck. & 0.08 & 0.05 & 0.05 & \\
\hline Cirsium arizonicum (Gray) Petrak. & 0.02 & 0.02 & 0.02 & \\
\hline Erigeron divergens Torr. \& Gray & 0.10 & 0.04 & & 0.01 \\
\hline Erigeron flagellaris Gray & 0.05 & 0.01 & & 0.02 \\
\hline $\begin{array}{l}\text { Eriogonum wrightii Torr. } \\
\text { Gutierrezia sarothrae (Pursh) Britt. \& }\end{array}$ & 0.03 & 0.08 & 0.03 & 0.02 \\
\hline Rusby & 0.35 & 0.05 & 0.18 & 0.03 \\
\hline Leucelene ericoides (Torr.) Greene & 0.08 & 0.08 & 0.08 & 0.05 \\
\hline Solanun elaeagnifolium Cav. & 0.02 & 0.02 & & \\
\hline Sphaeralcea angustifolia (Cav.) G. Don. & 0.01 & 0.01 & 0.01 & \\
\hline Sphaeralcea coccinea (Pursh) Rydb. & 0.04 & 0.04 & 0.04 & 0.01 \\
\hline Verbena bipinnatifida Nutt. & 0.02 & & 0.04 & 0.02 \\
\hline Verbena perennis Woot. & 0.01 & & 0.01 & 0.01 \\
\hline Total Forbs & 1.34 & 0.65 & 0.66 & 0.55 \\
\hline
\end{tabular}

'Total grasses is exclusive of blue grama.

Table 4. Mean vegetational composition of cover $(\%) \pm$ standard error of the mean by component and year for the continuous and short duration grazing pastures.

\begin{tabular}{lcc}
\hline \hline Component \\
Grazing treatment & \multicolumn{2}{c}{ Year } \\
\cline { 2 - 3 } & \multicolumn{2}{c}{1984} \\
\hline $\begin{array}{l}\text { Blue Grama } \\
\text { Continuous }\end{array}$ & $51.1 \pm 2.10$ & $58.4 \pm 1.51$ \\
$\quad$ Short duration & $63.2 \pm 1.87$ & $69.6 \pm 2.20$ \\
Other-Grass & & \\
$\quad$ Continuous & $35.4 \pm 2.13$ & $28.0 \pm 1.52$ \\
$\quad$ Short duration & $25.4 \pm 1.75$ & $20.4 \pm 2.09$ \\
Forbs & & \\
$\quad$ Continuous & $13.5 \pm 0.99$ & $14.4 \pm 1.02$ \\
$\quad$ Short duration & $11.4 \pm 0.88$ & $10.9 \pm 1.00$ \\
Shrubs & & \\
$\quad$ Continuous & $0.1 \pm 0.04$ & $0.1 \pm 0.05$ \\
$\quad$ Short duration & $0.1 \pm 0.06$ & $0.1 \pm 0.06$ \\
\hline
\end{tabular}

$\mathrm{kg} \bullet \mathrm{ha}^{-1}$. This pattern occurred every year except for 1982 when biomass of other grasses was similar (only $20 \mathrm{~kg} \bullet \mathrm{ha}^{-1}$ difference) between the 2 sets of pastures. Although forb biomass averaged over 6 years was higher on the short-duration pastures than on the continuously grazed pasture, the difference was not consistent over the years. 
Table 5. Mean' herbaceous vegetation production $\left(\mathrm{kg}^{1} \bullet \mathrm{ha}^{-1}\right) \pm$ standard error of the mean by component and year for the continuous and short duration graxing treatment.

\begin{tabular}{|c|c|c|c|c|c|c|c|}
\hline $\begin{array}{l}\text { Component } \\
\text { Grazing Treatment }\end{array}$ & 1980 & 1981 & 1982 & 1983 & 1984 & 1985 & Mean \\
\hline $\begin{array}{c}\text { Total Herbage } \\
\text { Continuous } \\
\text { Short duration }\end{array}$ & $\begin{array}{r}1,045 \pm 60 \\
913 \pm 84\end{array}$ & $\begin{array}{l}1,449 \pm 79 \\
1,514 \pm 93\end{array}$ & $\begin{array}{l}1,032 \pm 80 \\
1,161 \pm 84\end{array}$ & $\begin{array}{r}1,048 \pm 99 \\
962 \pm 83\end{array}$ & $\begin{array}{l}1,405 \pm 96 \\
1,539 \pm 171\end{array}$ & $\begin{array}{l}1,216 \pm 64 \\
1,196 \pm 111\end{array}$ & $\begin{array}{l}1,199 \pm 36 \\
1,214 \pm 48\end{array}$ \\
\hline $\begin{array}{l}\text { Blue Grama } \\
\text { Continuous } \\
\text { Short duration }\end{array}$ & $\begin{array}{l}454 \pm 75 \\
267 \pm 43\end{array}$ & $\begin{array}{l}656 \pm 81 \\
511 \pm 84\end{array}$ & $\begin{array}{l}488 \pm 61 \\
398 \pm 43\end{array}$ & $\begin{array}{l}225 \pm 36 \\
332 \pm 84\end{array}$ & $\begin{array}{l}533 \pm 66 \\
563 \pm 64\end{array}$ & $\begin{array}{l}501 \pm 67 \\
446 \pm 64\end{array}$ & $\begin{array}{l}476 \pm 29 \\
446 \pm 27\end{array}$ \\
\hline $\begin{array}{l}\text { Other-grass } \\
\text { Continuous } \\
\text { Short duration }\end{array}$ & $\begin{array}{l}424 \pm 76 \\
223 \pm 56\end{array}$ & $\begin{array}{l}532 \pm 87 \\
338 \pm 84\end{array}$ & $\begin{array}{l}426 \pm 78 \\
446 \pm 91\end{array}$ & $\begin{array}{l}398 \pm 64 \\
295 \pm 58\end{array}$ & $\begin{array}{l}477 \pm 79 \\
460 \pm 86\end{array}$ & $\begin{array}{l}475 \pm 83 \\
443 \pm 83\end{array}$ & $\begin{array}{l}455 \pm 32 \\
368 \pm 32\end{array}$ \\
\hline $\begin{array}{l}\text { Forbs } \\
\text { Continuous } \\
\text { Short duration }\end{array}$ & $\begin{array}{l}167 \pm 45 \\
423 \pm 104\end{array}$ & $\begin{array}{l}261 \pm 69 \\
666 \pm 134\end{array}$ & $\begin{array}{l}118 \pm 23 \\
317 \pm 85\end{array}$ & $\begin{array}{l}425 \pm 94 \\
335 \pm 66\end{array}$ & $\begin{array}{l}395 \pm 98 \\
476 \pm 129\end{array}$ & $\begin{array}{l}240 \pm 37 \\
190 \pm 50\end{array}$ & $\begin{array}{l}268 \pm 29 \\
401 \pm 42\end{array}$ \\
\hline
\end{tabular}

${ }^{\mathrm{T}}$ Yearly means calculated using $\mathrm{N}=24$, mean calculated using $\mathrm{N}=144$.

\section{Aboveground Net Primary Productivity}

Maximum productivity for blue grama was $9.2 \mathrm{~kg} \bullet \mathrm{ha}^{-1} \cdot \mathrm{da}^{-1}$ on the short-duration pastures from 6 July to 15 August (Table 6). Primary productivity for blue grama was consistently higher on the short-duration pastures than the continuously-grazed pasture. However, confidence intervals overlapped for each period, except for the 6 July-15 August period (Table 6). Growth rate of other grass species varied among the 2 sets of pastures, although growth

Table 6. Mean daily growth rate $\left(\mathrm{kg} \bullet \mathrm{ha}^{-1} \bullet \mathrm{da}^{-1}\right)$ standard error of the mean by growing period for the continuous and short duration grazing pastures 1985 growing season.

\begin{tabular}{lcccc}
\hline \hline \multirow{2}{*}{$\begin{array}{c}\text { Component } \\
\text { Grazing treatment }\end{array}$} & 1 & 2 & 3 & 4 \\
\cline { 2 - 5 } & \multicolumn{5}{c}{ Growing Period 1} \\
\hline Blue Grama \\
$\begin{array}{l}\text { Continuous } \\
\text { Short duration }\end{array}$ & $1.9 \pm 0.67$ & $5.7 \pm 1.79$ & $1.8 \pm 1.11$ & $3.7 \pm 1.18$ \\
Other-Grass & & & & \\
$\quad$ Continuous & $1.6 \pm 0.90$ & $1.6 \pm 1.80$ & $3.6 \pm 1.43$ & $2.5 \pm 2.10$ \\
Short duration & $1.7 \pm 0.42$ & $0.8 \pm 2.08$ & $3.5 \pm 1.53$ & $1.2 \pm 1.34$ \\
Forbs & & & & \\
$\quad$ Continuous & $3.4 \pm 0.65$ & $4.5 \pm 1.81$ & $2.7 \pm 1.29$ & $2.9 \pm 1.35$ \\
Short duration & $1.5 \pm 0.52$ & $1.8 \pm 1.30$ & $2.3 \pm 1.09$ & $2.3 \pm 1.58$ \\
Total & & & & \\
$\quad$ Continuous & $6.9 \pm 0.95$ & $11.7 \pm 1.46$ & $7.5 \pm 1.26$ & $9.1 \pm 2.04$ \\
Short duration & $5.5 \pm 0.89$ & $11.8 \pm 3.31$ & $8.6 \pm 1.87$ & $7.9 \pm 1.61$ \\
Precipitation & & & & \\
$\quad$ Continuous & $164^{2}$ & 1273 & $264^{4}$ & $264^{4}$ \\
Short duration & $146^{2}$ & $116^{3}$ & $240^{4}$ & $240^{4}$ \\
\hline
\end{tabular}

'Period 1 , (10 June to 22 August).

Period 2, (6 July to 15 August).

Period 3, (18 August to 12 October).

Period 4, (25 August to 12 October).

Periods overlap because rest periods overlapped in different pastures in shortduration regime.

2Received, I May through 21 August 1985.

3Received, 1 May through 14 August 1985.

‘Received, 1 May through 31 September 1985.

rate was generally higher for the continuously-grazed pasture. Forb productivity also tended to be higher for the continuouslygrazed pasture than for the short-duration pastures. Growingseason precipitation was also higher on the continuously-grazed pasture (Tables 1 and 6), and may have contributed to the higher productivity of other grass species and forbs.

\section{Discussion}

Differences in vegetational responses to short-duration and continuous grazing on blue grama rangeland were small. Total end-ofseason standing crop of all species was similar for all years of the study. These results agree with those of several other studies (Clatworthy 1984, Pitts and Bryant 1983, Reece 1986) that show small differences between short-duration and some other grazing regime or inconsistent differences. In the present study there were some indications that total basal plant cover and blue grama composition and productivity were responding to short-duration grazing, although mechanisms for this response are not clear. In the Edwards Plateau of Texas, mid grasses declined under shortduration grazing while the short grasses increased (Thurow et al. 1988). Apparently any increase in herbaceous vegetation under short duration grazing did not result from increased infiltration (Thurow et al. 1986, Warren et al. 1986, Weltz and Wood 1986, and Pluhar et al. 1987). Several of these studies indicate stocking can be increased moderately (10-20\%) under short-duration grazing with no detrimental impact on vegetation. Heavy, continuous stocking resulted in decrease in grass cover and in increase in forb cover (Pieper et al. In press). However, livestock responses to shortduration grazing were not superior to those under continuous grazing (Parker et al. 1987). Consequently, benefits from shortduration grazing are likely to come from ease of livestock handling, slightly higher stocking, and improved management necessary to implement short-duration grazing successfully (Dahl 1986).

\section{Literature Cited}

Anderson, D.M. 1988. Seasonal stocking of tobosa managed under continuous and rotation grazing. J. Range Manage. 41:78-83.

Armijo, L. 1982. Convention will provide opportunity to view Savory Grazing Method. Rangelands 4:217-219.

Bailey, O.F., L.A. Daugherty, and G.B. Donart. 1982. Soil survey of Fort Stanton Experimental Ranch-Phase I. New Mexico Agr. Exp. Sta. Spec. Rep. 43.

Branson, F.A. 1953. Two factors affecting resistance of grasses to grazing. J. Range Manage. 6:165-171.

Briske, D.D., and M.M. Kothmann (eds.). 1982. Proceedings of a national conference on grazing management technology. Texas A\&M Univ., College Station.

Brown, M.A., and S.S. Waller. 1986. The impact of experimental design on the application of grazing research results - an exposition. J. Range Manage. 39:197-199.

Clatworthy, J.N. 1984. The Charter Estate grazing trial. Results of the botanical analysis. Zimbabue Agr. J. 81:49-52. 
Dahl, B.E., P.F. Cotter, and D.D. Drbal. 1982. Renovation of kleingrass and tobosagrass pastures through grazing management. In: Guthery, F.S., and C.M. Britton (eds.) Noxious Brush and Weed Control 13:44. Range and Wildlife Manage. Texas Tech. Univ., Lubbock.

Dahl, Bill E. 1986. The west Texas experience in short duration grazing. In: Tiedeman, J.A. Proc. of the short duration grazing and current issues in grazing manage. Shortcourse. Coop. Exten. Ser., Washington State Univ., Pullman.

Evans, R.A., and R.M. Love. 1957. The step-point method of sampling-a practical tool in range research. J. Range Manage. 10:289-297.

Goodloe, S. 1969. Short duration grazing in Rhodesia. J. Range Manage. 22:369-373.

Hart, R.H., M.J. Samuel, P.S. Test, and M.A. Smith. 1988. Cattle, vegetation, and economic responses to grazing systems and grazing pressure. $J$. Range Manage. 41:282-286.

Heitschmidt, R.K., S.L. Dowhower, and J.W. Walker. 1987. Some effects of a rotational grazing treatment on quantity and quality of available forage and amount of ground litter. J. Range Manage. 40:318-321.

Heitschmidt, R.K., D.L. Price, R.A. Gordon, and J.R. Frasure. 1982. Short duration grazing at the Texas Experimental Ranch: Effects on aboveground net primary production and seasonal growth dynamics. $J$. Range Manage. 35:367-371.

Hurlbert, S.H. 1984. Pseudoreplication and the design of ecological field experiments. Ecol. Monogr. 54:187-211.

Kelton, E. 1982. Rancher boosts grazing on large ranch fenced in cells. Rangelands 4:258-260.

Lebgue, T., and K.W. Allred. 1985. Flora of the Fort Stanton Experimental Ranch, Lincoln County, New Mexico. New Mex. Agr. Exp. Sta. Res. Rep. 557.

Levy, E.B., and E.A. Madden. 1933. The point method of pasture analysis. New Zealand J. Agr. 46:267-279.

Parker, E.E., G.B. Donart, R.D. Pieper, J.D. Wallace, and J.D. Wright. 1987. Response of range beef cattle to different grazing management systems. New Mex. State Univ., Agr. Exp. Sta. Bull. 732.

Pieper, R.D., E.E. Parker, G.B. Donart, J.D. Wallace, and J.D. Wright. 1991. Cattle and vegetation response to 4-pasture rotation and continuous grazing systems. Submitted as New Mex. Agr. Exp. Sta. Bull. 756.

Pieper, R.D., J.R. Montoya, and V.L. Groce. 1971. Site characteristics on pinyon-juniper and blue grama ranges in south-central New Mexico. New Mexico Agr. Exp. Sta. Bull. 573.

Pieper, R.D., G.B. Donart, E.E. Parker, and J.D. Wallace. 1978. Livestock and vegetational response to continuous and 4-pasture, 1-herd grazing systems in New Mexico. pp. 560-562. In: Hyder, D.N. (Ed.). Proc. First Internat. Rangel. Congr.

Pitts, J.S., and F.C. Bryant. 1983. Cattle response to continuous and short duration grazing. In: Britton, C.M. and F.S. Guthery (Eds). Noxious Brush and Weed Control. 14:30-31. Range and Wildlife Manage., Texas Tech. Univ., Lubbock.

Pluhar, J.J., R.W. Knight, and R.K. Heitschmidt. 1987. Infiltration rates and sediment production as influenced by grazing systems in the Texas rolling plains. J. Range Manage. 40:240-243.

Ralphs, M.H., M.M. Kothmann, and C.A. Taylor. 1980. Vegetation response to increased stocking rates in short duration grazing. J. Range Manage. 43:104-108.
Reece, P.E., R.P. Bode, and G.D. Moeller. 1984. Frequency of plant species under high intensity-short duration grazing in western Nebraska. Abstr. Soc. Range Manage. Ann. Mtg. 37:188.

Reece, P.E. 1986. Short duration grazing research and case studies in Nebraska. In: Tiedeman, J.A. (Ed.) Proc. Short Duration Grazing and Current Issues in Grazing Management. Coop. Ext. Ser., Washington State Univ., Pullman.

Savory, A. 1978. A holistic approach to range management using shortduration grazing. In: Hyder, D.N. (Ed.) Proc. First Internat. Rangel. Congr., Denver, Colorado.

Savory, A. 1979. Range management principles underlying short-duration grazing. Beef Cattle Handbook. Agr. Serv. Found., Clovis, California 16:374-379.

Savory, A. 1983. The Savory Grazing Methods or Holistic Resource Management. Rangelands. 5:155-159.

Savory, A. 1988. Holistic resource management. Island Press. Covelo, California.

Savory, A., and S.D. Parsons. 1980. The Savory Grazing Method. Rangelands. 2:234-237.

Skovlin, J. 1987. Southern Africa's experience with intensive short duration grazing. Rangelands 9:162-167.

Smoliak, S. 1974. Range vegetation and sheep production at three stocking rates on stipa-bouteloua prairie. J. Range Manage. 21:23-26.

Soltero, S., F.C. Bryant, and A. Melgoza. 1989. Standing crop patterns under short duration grazing in northern Mexico. J. Range Manage. 42:20-21.

Sparks, K.D. 1987. Ranching efficiency in south Texas-a rancher's viewpoint. Rangelands 9:22-23.

Thurow, T.L., W.H. Blackburn, and C.A. Taylor, Jr. 1986. Hydrologic characteristics of vegetation types as affected by livestock grazing systems, Edwards Plateau, Texas. J. Range Manage. 39:505-509.

Thurow, T.L., W.H. Blackburn, and C.A. Taylor. 1988. Some vegetation responses to selected livestock grazing techniques, Edwards Plateau, Texas. J. Range Manage. 41:108-113.

Tiedeman, J.A. (Ed.). 1986. Short duration grazing. Proc. Short Duration and Current Issues Grazing Manage. Shortcourse. Coop. Ext. Ser. Washington State Univ., Pullman.

Tiedeman, J.A., and R.V. Ecret. 1986. Discussion of the practical applications of time-controlled grazing. In: Tiedeman, J.A. (Ed.) Short Duration Grazing. Coop Ext. Ser., Washington State Univ., Pullman.

Tiedeman, J.A., and R.V. Ecret. 1986. Discussion of the practical applications of time-controlled grazing. In: Tiedeman, J.A. (Ed.) Short Duration Grazing. Coop. Ext. Ser., Washington State Univ., Pullman.

Walker, J.W., and E.W. Richardson. 1986. Replication in grazing studieswhy bother? In: Bonham, C.D. (Ed.) Statistical analysis and modeling of grazing systems. Sym. Proc. Soc. Range Manage. Annu. Meet. Denver, Colo.

Warren, S.D., W.H. Blackburn, and C.A. Taylor, Jr. 1986. Effects of season and stage of rotation cycle on hydrologic condition of rangeland under intensive rotation grazing. J. Range Manage. 39:486-491.

Weltz, M., and M.K. Wood. 1986. Short duration grazing in central New Mexico: Effects on infiltration rates. J. Range Manage. 39:365-368. 